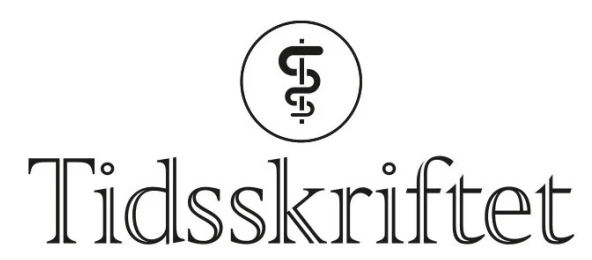

DEN NORSKE LEGEFORENING

\title{
Hva er helsespråk?
}

\author{
SPRÅKSPALTEN
}

\section{ERLEND HEM}

erlend.hem@medisin.uio.no

Erlend Hem er professor i atferdsmedisin ved Universitetet i Oslo, instituttsjef ved

Legeforskningsinstituttet og leder av Gruppe for norsk medisinsk fagspråk.

\section{MAGNE NYLENNA}

Magne Nylenna er professor i samfunnsmedisin ved Universitetet i Oslo, fagdirektør i Folkehelseinstituttet og medlem av Gruppe for norsk medisinsk fagspråk.

\section{Helsespråk er språklig kommunikasjon om helse og sykdom i en helsefaglig sammenheng. Et godt og klart helsespråk er nødvendig for både helsepersonell, pasienter, pårørende og publikum.}

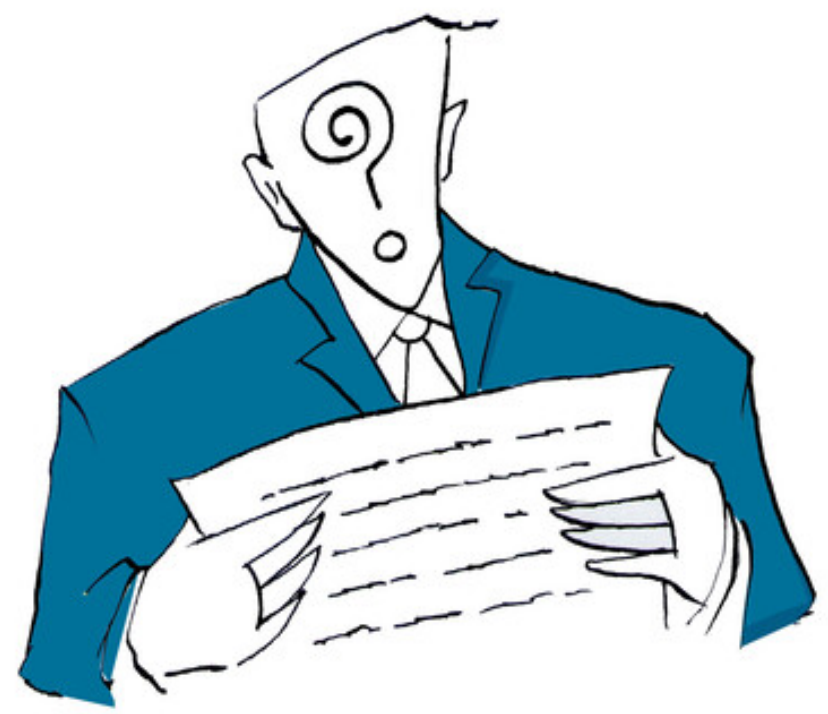

Illustrasjon: romeocane1/iStock

Hver tredje person i Norge har mangelfull helsekompetanse, ifølge en fersk undersøkelse av 6 ooo voksne personer (1). De har problemer med å finne, forstå og benytte seg av helseinformasjon (ㅁ) . Nesten halvparten av befolkningen klarer ikke å vurdere informasjon 
de får om helsespørsmål. Det gjaldt også informasjon om den pågående koronapandemien (1).

Forskerne studerte ikke språkbruk spesifikt, men kommunikasjonsproblemer mellom helsepersonell og pasienter er velkjent (3,4.). Behovet for helsekompetanse er $\emptyset$ kende fordi moderne medisin blir stadig vanskeligere å orientere seg i (5).

\section{Forståelig språk er avgjørende}

Språket er en avgjørende suksessfaktor i all kommunikasjon. Et forståelig språk er en forutsetning for god kommunikasjon mellom helsepersonell og pasienter, mellom helsemyndigheter og befolkningen, og internt $\mathrm{i}$ helsetjenesten. Medisinens utvikling, spesialisering og kunnskapstilfang har skapt nye ord og uttrykk som ikke bare er vanskelige for allmennheten, men ofte også for helsepersonell. Omsorgen for enkeltpasienter er teambasert, og effektivt samarbeid mellom ulike profesjoner og yrkesgrupper krever standardisert språkbruk.

Klarspråk brukes som betegnelse på «kommunikasjon med så tydelig ordlyd, struktur og visuell utforming at leserne i målgruppen finner informasjonen de trenger, forstår den og kan bruke den» (ㅁ). Med utgangspunkt i stortingsmeldingen om norsk språkpolitikk fra 2007/08 (7.) er det etablert en klarspråkkampanje i offentlig sektor som et samarbeid mellom Språkrådet, KS og Digitaliseringsdirektoratet (ㅁ). Dette omfatter også helsesektoren.

\section{Bok om helsespråket}

I en ny bok med tittelen Helsespråk har vi samlet 23 bidrag fra 25 forfattere, som skriver om ulike sider ved kommunikasjon i helsevesenet, og der begrepet helsespråk blir definert og relatert til medisinsk fagspråk (9.). 


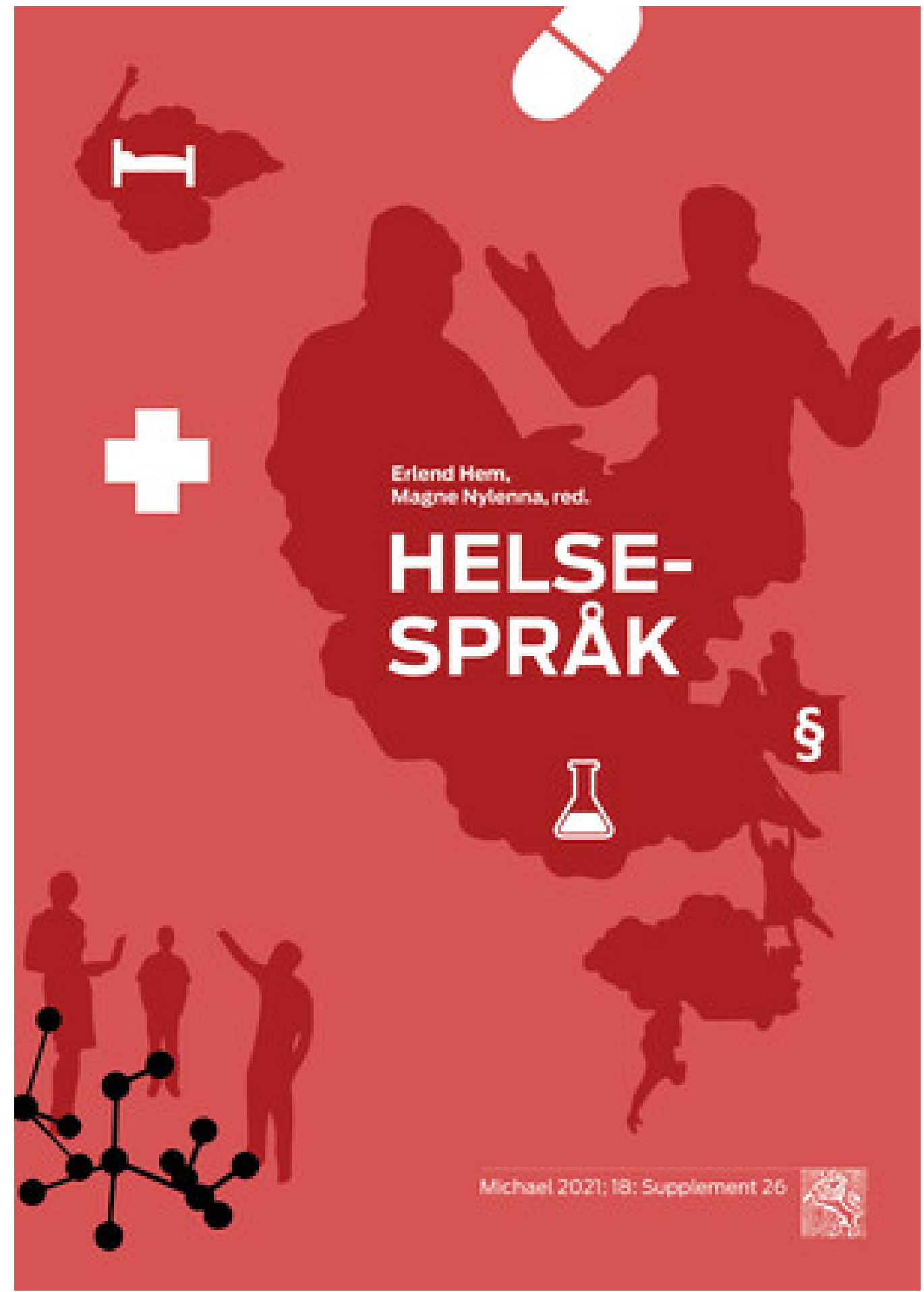

Aktuell bok: Helsespråk.

Forenkling av innkallingsbrevene i spesialisthelsetjenesten er et godt eksempel på arbeidet med helsespråk. Helsekommunikasjon under koronapandemien og utfordringene for helsepersonell med norsk som andrespråk blir også omtalt i boka. Helsevesenet kan ha mye å lære av andre sektorer som arbeider systematisk med språket. Boka inneholder også kapitler om klarspråk innen juss, i Arbeids- og velferdsdirektoratet og i akademia.

Boka publiseres som supplement til tidsskriftet Michael, som utgis av Det norske medicinske Selskab (9.). Den blir åpent tilgjengelig på www.michaeljournal.no. Bak initiativet står en tverrfaglig gruppe med representanter fra Språkrådet, Helse Sør-Øst RHF, Direktoratet for e-helse og Gruppe for norsk medisinsk fagspråk, samt Tidsskrift for Den norske legeforening. Boka lanseres på et nettseminar 21.5.2021 som er åpent for alle interesserte. 


\section{LITTERATUR}

1. Le C, Finbråten HS, Pettersen KS et al. Befolkningens helsekompetanse, del I. Rapport IS-2959. Oslo: Helsedirektoratet, 2021. https://www.helsedirektoratet.no/rapporter/befolkningenshelsekompetanse/ Lest 19.3.2021.

2. Sirum-Eikre M. - Mange forstår ikke det de sier. NRK 25.1.2021. https://www.nrk.no/norge/--mangeforstar-ikke-det-de-sier-1.1534246o Lest 19.3.2021.

3. Falkenberg SH, Kristensen PL, Andersen AMN. Lægfolks opfattelser af lægers ord. En undersøgelse af forståelsen af almindeligt anvendte medicinske ord. Ugeskr Læger 2004; 166: 152-6. [PubMed]

4. Thorsen H, Witt K, Brodersen J. For mange svære ord i skriftlig kommunikation fra sundhedsvæsenet. Ugeskr Læger 2012; 174: 925-30. [PubMed]

5. Hem E. Hva er egentlig helsekompetanse? Tidsskr Nor Legeforen 2020; 141. doi: 10.4045/tidsskr.20.0463. [CrossRef]

6. Språkrådet. Klarspråk - hva og hvorfor? https://www.sprakradet.no/Sprakarbeid/Detoffentlige/Klarsprak/ Lest 19.3.2021.

7. St.meld. nr. 35 (2007-2008). Mål og meining. Ein heilskapleg norsk språkpolitikk. https://www.regjeringen.no/contentassets/50816e814a9c46169bd69dc2odd746a3/nnno/pdfs/stm2007200800350oodddpdfs.pdf Lest 19.3.2021.

8. Språkrådet. Bruk klarspråk. https://www.sprakradet.no/klarsprak/ Lest 19.3.2021.

9. Hem E, Nylenna M, red. Helsespråk. Michael 2021; 18: Supplement 26.

Publisert: 16. april 2021. Tidsskr Nor Legeforen. DOI: 10.4045/tidsskr.21.0224

(C) Tidsskrift for Den norske legeforening 2023. Lastet ned fra tidsskriftet.no 26. april 2023. 